\title{
The Second World War
}

The years from 1939 to 1945 were perhaps the most glorious period of Norwegian shipping; the aftermath of the war was not a particularly proud time.

Norway's neutrality policy was scuttled when Nazi Germany invaded the country on 9 April 1940, but the fleet-the majority of which was in neutral or Allied waters and ports-remained outside German control. Instead, the ships were requisitioned by the Norwegian government, paving the way for Nortraship_often referred to as "the world's largest shipping company." The merchant marine played a vital role in the Allied fight against the Axis powers_-but at a high cost. More than 700 ships were lost, and around 3700 sailors lost their lives.

In 2012 the thriller-author Jon Michelet's first novel about Halvor Skramstad, En sjøens helt - Skogsmatrosen [A hero of the seas - The sailor from the woods], became a surprising best-seller. The initial print run of the first book was 5000 copies; by 2015 the first four volumes in the series had gone on to sell more than 600,000 copies, and the film rights had been picked up by Nork Rikskringkasting [the Norwegian Broadcasting Corporation]. With the series En sjøens helt, Michelet and 
the fate of his fictional hero entered the national psyche. In a poll by the leading newspaper, Verdens Gang, in 2014, to commemorate the 200th anniversary of the Norwegian constitution, the anonymous Krigsseiler [War sailor] was voted "The most important Norwegian" since $1814{ }^{1}$

This was not the first time that Jon Michelet—who had trained and worked as a seaman himself_-dealt with the sea, seafarers and shipping in his books. Previously, the author had presented shipowners as unscrupulous capitalist crooks in his crime novels, with some success. ${ }^{2}$ This time, however, the angle was more positive-the seafarer as hero, rather than the shipowner as scoundrel. In fact, the series about Halvor Skramstad, Michelet's magnum opus, had a specific purpose: Michelet wanted to create a memorial to the Norwegian war sailors.

Michelet's books are thoroughly researched, generally well-written and have a gripping plot. However, their immense success undoubtedly reflects the manner in which the main topic managed to grab the attention of the Norwegian public. There are three main reasons that Norwegian wartime shipping, and the history of the merchant seafarers, appealed to readers.

First, the political situation under which the war sailors rose to prominence was dramatic and provides a proud and powerful backdrop to the novels. Although Norway was occupied by Nazi Germany, the sailors were working on behalf of "Free Norway," aiding the Allied efforts at high risk. The Norwegian military had to rapidly give up their attempts at defending the mainland Norwegian territory, but the ships and seafarers continued the fight. The transport of oil and petroleum products was particularly dangerous and difficult, but crucial to the Allied resistance and eventual victory. The oil tankers were "the artery of the Allied fight for victory." Winston Churchill's alleged claim that the Norwegian seafarers were worth more than a million soldiers is an oft-repeated quote. ${ }^{4}$

\footnotetext{
${ }^{1}$ More than 20,000 people voted in the poll, and the anonymous war sailor got 12 per cent of the votes-more than twice as much as former Prime Minister Einar Gerhardsen in second place; Verdens Gang, 030314, 16.

${ }^{2}$ See, for instance, his debut Den drukner ei som henges skal (1975) or Panamaskipet (1984), as well as the play Matros Tore Solem og hans skip (1979), coauthored with Gunnar Bull-Gundersen.

${ }^{3}$ Admiral of the Fleet, Viscount Cunningham of Hyndhope, quoted in Rasmussen $(1964,9)$.

${ }^{4}$ The origins of the quote are unsure; it was sometimes referenced to an editorial in The Motor Ship, and has also been attributed to others rather than Churchill, including the US Admiral Emery Land (see Lindbæk 1948, 17); Anthony Eden (see Steen 1948, 110); President Roosevelt (see Vikøren 1986, 3); and Carl Joachim Hambro (see Hambro 1945, 24).
} 
Second, as maritime employment was still widespread, many Norwegians had a war sailor in their immediate family. Moreover, these seafarers were the Norwegian fighters-both their losses and the tactical results of their struggles exceeded those of the regular armed forces: "For the majority of the Norwegian population in Norway during the German occupation, the war years were a challenge of the more prosaic kind. The aim was human and material survival. [...] Norwegian sailors in the Nortraship fleet had a different wartime experience. They were at war." 5

Finally, there is an element of shame-maybe a "sin of omission"related to how the war sailors were treated after the war. Part of this guilt is related to the so-called "Nortraship-fund" and the manner in which the war sailors had to fight for their compensation and rights. Jon Michelet's book series paid respect to the seafarers. The readers gave them the honour that they should have received shortly after the war.

The seafarers and the fleet played a crucial role during the Second World War, as part of the war effort and as a source of funding for the government in exile. Due to the mobility and global reach of Norway's most important export sector, money could be made even though the country was occupied. The massive revenues from the ships that had been requisitioned gave the Norwegian government in London resources that far exceeded those that other countries had.

The funding came at a substantial cost. The seafarers were subject to terrible pressure, stress and trauma, and many found it difficult to return to normal life after the war. For many Norwegian seafarers the war lasted for several decades, as they fought personal battles over and over again. The Second World War also began earlier for the seafarers than for other Norwegians.

\section{The Forgotten War}

In Norwegian history books, the Second World War reaches Norway on 9 April 1940, with the German invasion. For Norwegian seafarers, however, the battle had already lasted more than six months. Almost 60 ships had been sunk and more than 400 Norwegian seafarers had been killed

\footnotetext{
${ }^{5}$ Hjeltnes (1995, 10-11).
} 
by the time the German soldiers started marching on Norwegian soil. The initial months of the war are commonly referred to as "The Phoney War" —or even "The Bore War" — due to the shadow-boxing among the belligerents and the lack of substantial military action. However, for Norwegian seafarers, the Phoney War was very real.

Initially, both the political situation-a mainly German-British conflict with Norwegian neutrality-and the challenges were the same as during the First World War. The war insurance scheme that had been established to ensure that Norwegian ships could sail, was disbanded after the First World War. In 1935 a similar institution, "Den norske Krigsforsikring for Skib - Gjensidig Forening" was established. On the very same day that France and the UK declared war on Germany, the War Insurance Fund, after discussions with the Norwegian Shipowners' Association, Nordisk Skipsrederforening [the Nordic Shipowners' Association — which deals primarily with legal issues] and the Norwegian government, ordered vessels in international waters to seek Norwegian or neutral ports as quickly as possible, and to await further orders there. Thus, the charterers lost their right to manage the ship.

A substantial portion of the ships that were redirected were on their way to British ports - the symbiosis between Norwegian shipping and British trade was still strong. However, with the change in propulsion of the Norwegian fleet-from coal-driven steam to diesel-driven motor engines - a British threat of cutting off the coal supply would not harm Norwegian shipping as much as during the previous war. Moreover, the large share of tankers-Norwegians controlled around 40 per cent of the independent tanker fleet-implied that the ships would be particularly important for the provision of fuel for the British war effort. So, a neutral Norway — with a need for provisions — and a UK at war — with a need for transport - clearly echoed the state of affairs from the First World War. However, the relative strength of the two parties had definitely changed.

Nevertheless, the practical solutions were similar. The Norwegian authorities worked behind the scenes, gently pressuring the shipowners to come to a solution with the UK and urging them to send a delegation to London to negotiate; "in the game [to ensure essential imports] Norway could use the Norwegian merchant marine as a trump card."6

${ }^{6}$ Undersøkelseskommisjonen av 1945 (1945, 55). 
This required control of the fleet. A licensing system for the signing or renewal of charters was introduced, ensuring that the authorities had some control. The Board of the Norwegian Shipowners' Association reluctantly introduced measures that gave them the authority to manage the ship on behalf of the owners. ${ }^{7}$

An accord with the British was reached in November 1939 when a delegation — with wide authority — entered into what is referred to as the Scheme Agreement. The agreement was never formally signed. In order to protect Norwegian neutrality, it was only initialled and made to look like a "gentlemen's agreement." ${ }^{8}$ Norwegian shipowners put some 150 tankers-around 1.2 million gross register tons (grt)—at British disposal at agreed freight rates, as well as around 150,000 grt of tramp tonnage. This came in addition to tonnage amounting to around 450,000 grt that had already been chartered to the British, and implied that the Allies had access to around 40 per cent of the Norwegian merchant marine. ${ }^{9}$

The access to the Norwegian fleet was important — both the Netherlands and Denmark refused to enter into similar agreements. ${ }^{10}$ During the First World War, David Lloyd George, the British Prime Minister, had pointed out that "The road to victory, the guarantee of victory, the absolute assurance of victory is to be found in one word - ships; and a second word ships; and a third word - ships." ${ }^{11}$ As in that war, Norway's substantial merchant marine meant that the country could play a decisive role in the outcome. And during The Phoney War, the situation was very much like it had been some 20 years earlier. Norwegian ships were neutral—but

\footnotetext{
${ }^{7}$ Thowsen $(1992,58)$.

${ }^{8}$ Nilsen and Thowsen (1990, 24).

${ }^{9}$ The exact figures differ between various sources, as some include subsequent additions to the agreement.

${ }^{10}$ While Norway was concerned with its access to British imports, the Danes primarily cared about access for their exports. Not until the British threatened to close their market for Danish agricultural commodities, did the Danes sign an agreement. Given that the agreement was signed in early April 1940, around a week before the German invasion of Denmark, it had limited practical relevance. When Denmark capitulated, ships available to the Allies were confiscated. Greece (in February 1940) and Sweden (in December 1939) also entered into tonnage agreements with the UK, though the amount of shipping capacity was much lower than in the Norwegian case; see Thowsen (1992, 88-98) for an overview of the neutral fleet.

${ }^{11}$ Address to the American Club in London, 12 April 1917; see Horne (1923, 143) for a transcript.
} 
leaning heavily towards the west. For Norwegian seafarers sailing in British convoys in late 1939 and the first part of 1940, there were no doubts at all about which side they were on.

Another similarity with the 1914-1918 war was the question of naval strength. The German Kriegsmarine had clear geographical disadvantages. Control of the sea lanes and other naval concerns were part of the basis for the German decision to invade Norway in April 1940. German submarines, and in particular the surface fleet, could benefit from the long and rugged coastline, and use its shelter to challenge the British domination of the North Sea. ${ }^{12}$ The invasion was partly a pre-emptive strikethe Germans feared that if Norway fell into British hands, the North Sea would be completely closed to them. The strategic role of Narvik, as basis for winter shipments of crucial Swedish iron ore, also played an important part in the German decision to invade.

These tactical factors were hardly a secret at the time, but the Norwegian preparations for a potential German invasion were nevertheless famously botched. While the Norwegian merchant marine was for the most part modern, and impressively so in an international perspective, the opposite was the case for the Norwegian navy. Of its 63 vessels, only 19 had been launched after the First World War. The majority-including the four main warships - had been built in the period 1874-1918, and were badly maintained. Still, the antiquity of the fleet had some practical advantages - many of the reservists that would be called up had not been trained for more than two decades, and would have had no knowledge about how to operate more modern vessels. ${ }^{13}$

As a result of the limited military potential of the Norwegian naval defence and the strategic importance of the Norwegian coast, the British had already intervened and infringed upon Norwegian neutrality. In February 1940, British forces entered Norwegian waters and boarded a German vessel, Altmark, which was used to transport prisoners of war.

\footnotetext{
${ }^{12}$ While the submarines could perform the kind of hidden and deadly work they had done during the previous war, the German surface navy was not impressive. Admiral Raeder, Commander in Chief and one of the staunchest supporters of the attack on Norway, famously confessed to his diary that the navy was so weak that it could do no more than "show that they know how to die gallantly"; see for instance Bird (2006).
}

${ }^{13}$ Undersøkelseskommisjonen av 1945 (1945, 42-43). 
Given that Norwegian inspections on three separate occasions had failed to discover the around 300 prisoners that were hidden in the hold of the ship, the British double-check was warranted.

The Altmark incident provided Norway with a diplomatic dilemmathe case was a clear sign that neither of the belligerents really respected Norway's neutrality. Slightly less than two months later this became patently evident. On 8 April British forces placed mines in Norwegian waters, and a Polish submarine, which was part of a Royal Navy flotilla, torpedoed the general cargo carrier Rio de Janeiro, a ship full of German soldiers on the South Coast. The approximately 300 German soldiers on the Rio de Janeiro were on their way to Bergen. A larger group of around 1000 soldiers were onboard the heavy cruiser Blücher, which was sunk in the Oslofjord in the early hours of 9 April. The German invasion was underway.

The Blücher sinking "bought time" for the Norwegian authorities, including the government and King Haakon VII. They were able to leave Oslo, and make their way slowly and steadily northwards and then westwards. At the beginning of June the king, the crown prince and most of the government arrived in Scotland. From here, they travelled to London, in order to follow up on their decision of 7 June to move the seat of government abroad.

Although the royal family and the government escaped, the German attack-Operation Weserübung-succeeded in gaining control of much of the crucial infrastructure. Among the first installations targeted by the forces from the Third Reich were the country's two short-wave radio transmitters, Bergen Radio and Oslo Radio. These were the main-and fastest-means of communication between Norway and the valuable merchant marine. The Germans used them to send out messages urging Norwegian vessels to return home or go to neutral ports, preferably in Spain or Italy. ${ }^{14}$

\section{Nortraship}

More than 1000 Norwegian ships were sailing in foreign waters, or anchored in foreign ports, when the Germans invaded. Around 30,000 Norwegian seafarers were suddenly cut off from their home country, with

${ }^{14}$ Thowsen (1992, 102-103); see also Rosendahl (2015). 
the connections to their homes and families severed. ${ }^{15}$ The fact that Norway refused to bow to the Nazi Germans, made the status of Norwegian ships and seafarers complex. In the case of Denmark, which had been attacked at the same time and where the government had capitulated, the British authorities confiscated the vessels and gave them British flag and British terms. A similar solution was likely for the Norwegian fleet, until the country joined the Allies and their fight. Then another dilemma arose: striking the right balance between national and business interests. It is telling that one of the most detailed books about the manner in which the merchant marine was operated during the war has the far from subtle subtitle "Profit and patriotism." 16

Preparations for a solution occurred along two parallel tracks. In Norway, the government fled north, a few steps ahead of the German forces. Slightly less than two weeks after the invasion, on 22 April, at a cabinet meeting held in an old coaching inn, they decided to requisition the right to use all Norwegian ships larger than 500 grt. The Norwegian merchant marine would be under government control. The shipowner Øivind Lorentzen, who had been appointed head of the Shipping Directorate in 1939, was instructed to go to London as quickly as possible and oversee the practical matters.

Around the same time, in London, preparations were under way to build an infrastructure that could control and manage the fleet. By the time Lorentzen arrived at the end of April, the press had been informed that the Norwegian Shipping and Trade Mission was about to start its business. Four hours before Lorentzen arrived, the offices at 144 Leadenhall Street in the City had opened their doors. ${ }^{17}$ The organization's leading managers were Norwegian, but the offices were also staffed with British and American personnel.

The London office quickly grew out of its rented floor in Leadenhall Street, and Nortraship expanded both within and outside the building. Due to lack of space and frequent evacuations during the German air

\footnotetext{
${ }^{15}$ Hauge and Hartmann (1951, iii).

${ }^{16}$ Thowsen (1992, 104-107).

${ }^{17}$ Thowsen (1992, 57-59). The formal name, the Norwegian Shipping and Trade Mission, was seldom used; the organization was known by its telegram address, Nortraship.
} 
raids on central London, in October 1940 parts of the activities were moved to Sunningdale, south-west of the city. The facilities - a former Italian-run convent - were far more agreeable than those in the crowded City. Garden parties with friendly competitions - tug-of-war and football matches between seafarers and office personnel—were held when King Haakon VII arrived for annual inspections. In 1941 he told the participants that when he looked at the huge office staff gathered in Sunningdale, he could "better understand his position as the world's largest shipowner."18

The daily operation of Nortraship saw a number of challenges. The lines of command were difficult due to communication problems. On the one hand, information was vital to operate the fleet; on the other hand, it was crucial that this information did not fall into enemy hands. In the end, the solution became a wide network of branches. By the beginning of 1944 the Nortraship operation in London consisted of 17 individual departments, some divided into as many as five sections, while the New York office had one department more. Nortraship had 52 branch offices or representative offices, affiliated with either New York or London, in 26 different countries. ${ }^{19}$

Some shipowners were involved at high levels in the organization, and had to balance their own and Nortraship's interests, while others were stuck in occupied Norway and could not influence what happened to their tonnage. The Germans had been interested in taking control of the Norwegian Shipowners' Association, but the Nazi-friendly owners did not succeed in taking over until the beginning of 1942. Later that same year, the occupants started to round up shipowners with "unclear" loyalties - typically those with vessels in the Nortraship fleet and a limited willingness to cooperate. More than 300 owners withdrew from the association, and a parallel organization was established..$^{20}$

Among the shipowners working for Nortraship, one potential problem was that they could make decisions and transactions that would benefit

\footnotetext{
${ }^{18}$ Woxholth $(1965,50)$.

${ }^{19}$ Mossige (1989, 283-289).

${ }^{20}$ See Pettersen 1992 for an introduction to the fleet in Norway- "the home fleet" - which made up 45 per cent of the number of ships, but only around 15 per cent of the Norwegian tonnage. For an interesting and personal account by a shipowner left in Norway, see Høegh (1970, 30-42). Given that this book deals with Norwegian shipping in the international market, the home fleet will by and large be ignored here.
} 
their own interests, rather than Nortraship as a whole. Øivind Lorentzen was criticized for appointing his son to a central position, and it was also suggested that the two had led to losses for Nortraship by keeping "their own" Nopal-line in South America going. After long deliberations, a government-appointed committee in 1943 concluded that there were reasons for the criticism of some business decisions, but no basis for any stronger reaction. ${ }^{21}$

Another challenge was the ability to ensure cooperation among strong and powerful individuals who were used to being at the top. Antagonism between Øivind Lorentzen and Ingolf Hysing-Olsen, who built up the London office before Lorentzen's arrival, was partly solved when Lorentzen moved to New York to manage the organization there. Subsequently a number of strong personalities tried to find their positions in the organization. Hilmar Reksten, from Bergen, was an excellent shipping man, but hardly a diplomat, and was involved in a number of controversies both in London and New York. Erling Dekke Næss commenced his work in New York with a handicap: he was viewed with scepticism by many of his colleagues, as he had built up his fleet under foreign flag.

Arne Sunde, the only Liberal member of the London Cabinet, became Minister of Shipping when that post was established on 1 October 1942. ${ }^{22}$ That placed him neatly in the line of fire between the politicians, who wanted control of Nortraship, and the Nortraship management, who wanted as little political involvement as possible. He was also a useful lightning rod in the discussions with the British about the allocation of the Norwegian ships.

\section{Exile on Broad Street}

The international orientation of the United States in the interwar period is a debated topic. While some claim that the United States followed a policy inspired by the old British ideas of "splendid isolation," others claim that

\footnotetext{
${ }^{21}$ See Thowsen (1992, 229-240, 243-248 and 281-288).

${ }^{22}$ Sunde had previously been Consultative Councillor of State without portfolio, one of two government members not from the Labour Party, and also headed the Ministry of Provisioning. $\mathrm{He}$ arrived in the UK on HMS Galatea, together with Øivind Lorentzen and around 200 crates of the gold that had been retrieved from the headquarters of the central bank.
} 
the policy was internationalist, but based on economic involvementbanks not tanks. ${ }^{23}$ Regardless of the actual situation before Pearl Harbor, the Japanese attack changed the duration - if not the outcome - of the war. Just as the United States tipped the scales when it entered the First World War, the US entry into the Second World War was a decisive moment. After that, as Winston Churchill famously remarked: "Hitler's fate was sealed. Mussolini's fate was sealed. [The Japanese] would be ground to powder. All the rest was merely the proper application of overwhelming force." ${ }^{24}$

Nortraship had a presence in the United States for a long time before the Americans entered the war, mainly as a result of the substantial shipping activities in and around American waters. It was difficult to control this business from London, and uncertainty about the British ability to withstand the German attacks gave another impetus to establish an office in the United States. When a division of labour between the two offices was determined at the end of 1940, the New York office, located on Manhattan's Broad Street, was given the task to manage around one-third of the Nortraship vessels. However, a relatively large proportion of these ships were "free," in other words not included in the collective agreements with the Allies. Consequently, the shipping activity-management, operation, chartering-was much more differentiated than business conducted from the London office. However, financial responsibility was delegated to the London office, due to its proximity to the Bank of England and the Treasury, and in order to facilitate cooperation with the exiled Norwegian Ministry of Finance.

The operation of the fleet occurred more or less on normal terms. Similar to during the First World War, insurance was an important cost factor. The ships were insured through Lloyd's-conveniently located just around the corner from Nortraship's offices in the City. For a while Nortraship partly functioned as own insurer. Although the idea was that maintenance should take place as usual, this became difficult when the demands of the war dictated otherwise. The strict discipline of the convoys increased wear and tear, and ships sometimes had to take unsuitable cargoes. Most ships were issued with special equipment-additional life boats, armour, guns, protection against mines, and so on.

\footnotetext{
${ }^{23}$ See Braumoeller (2010) for an overview of the debate.

${ }^{24}$ Churchill $(1950,539)$.
} 
The US entry into the war implied that the question of the Norwegian tonnage became a trilateral problem-British, American and Norwegian interests all had to be taken into account. In late 1942 the remaining "free" ships flying the Norwegian flag were to be included more closely in the Allied operation. During the negotiations, Erling Dekke Næss skilfully played an inexperienced American (David Scoll) against a slightly arrogant British representative (William Weston). The end result was the Hogmanay Agreement, signed on New Year's Eve 1942 and given the Scottish name for a new year's gift. In addition to questions about the chartering and payment of the tonnage, the agreement took into account questions of market access and tonnage availability after the war, in particular with regard to the liner trade. ${ }^{25}$ This dichotomy between the short-term, strategic and military goals and the long-term question of Norwegian competitiveness after the return of peace was a crucial element of the Nortraship experience; the country was "Allied and competitor." 26

One of the most difficult issues in connection with the Nortraship organization was the question of salaries. In October 1942, the Prime Minister and other Cabinet members held a meeting with four members of the Norwegian Seamen's Mission's clergy. Their message to the government was that something was afoot among the seamen. The previous year they had tried to talk to the Minister of Finance about the high salaries in the London administration. Strong words, like "blood money," were used about the salaries that the bureaucrats received. ${ }^{27}$ The "administrators" working under relative safe circumstances in the Nortraship officeseven those outside the war zone-were earning more money than the seafarers risking their lives in the middle of the war theatre.

The transfers of funds from Nortraship to the government were initially specified as taxes and tonnage fees. Subsequently, the amounts necessary to balance the budgets were just registered as "Transfer from Nortraship. ${ }^{28}$ In total almost $£ 80$ million was transferred from Nortraship

\footnotetext{
${ }^{25}$ See Thowsen (1992, 409-423) and Næss (1977, 112-114).

${ }^{26}$ This is the subtitle of Basberg (1993), which succeeds Thowsen (1992) and concentrates on Nortraship in the period from the beginning of 1943 until the 1964 settlement.

${ }^{27}$ Undersøkelseskommisjonen av 1945, Volume I, 1945, 27; pages 118-139 deal specifically with Nortraship.

${ }^{28}$ Undersøkelseskommisjonen av 1945, Volume IV, 1947, 94.
} 
to the Norwegian exile government in the period from 1 July 1940 to 30 June 1945-making up almost 90 per cent of the total government revenues in this period. ${ }^{29}$ The revenues from Nortraship were important both during the war and in the reconstruction period. The currency principle-that revenues should preferably be in dollars, but expenses should preferably be paid in pounds sterling - turned out to be very wise, and created some leeway in a period of dollar shortages.

In addition to these pecuniary considerations, Nortraship had another important role-one that affected the long-term development and competitiveness of Norwegian shipping. Nortraship enabled the Norwegian authorities and shipping community to establish or strengthen political and business links to other Allied countries during the war. Moreover, it created a sense of unity among those in exile. Shipowners, shipping company clerks, brokers, lawyers, bankers and bureaucrats shared difficult times and forged friendships and relations that would be very useful in the post-war period.

At the end of the war, it was estimated that Nortraship had an operating profit of approximately NOK550 million. However, this underestimated charter and insurance transfers, as well as profits on the sale of ships that the Norwegian authorities bought from the British during the war. When the books were finally closed, in the early 1960s, they showed a profit of almost NOK819 million, almost three times the value of the gold reserves that were rescued in April $1940 .{ }^{30}$ The more than NOK800 million that the authorities received was around 18 per cent of the total Nortraship revenues. The majority of the around NOK4.5 billion Nortraship settlement was distributed to the various shipping companies according to a detailed set of calculations on a ship-by-ship basis. Among the important elements was insurance compensation for ships that had been sunk, which made up around 31 per cent of the "costs." 31

As Fig. 5.1 shows, the pattern of loss of life and ships during the Second World War echoes the pattern during the previous war. There

\footnotetext{
${ }^{29}$ Undersøkelseskommisjonen av 1945, Volume IV, 1947, 95.

${ }^{30}$ Norway, Parliament, Stortingsmelding 76 (1963-64) 13-15.

${ }^{31}$ See Basberg 1993, 327-345 for a detailed overview of the settlement.
} 


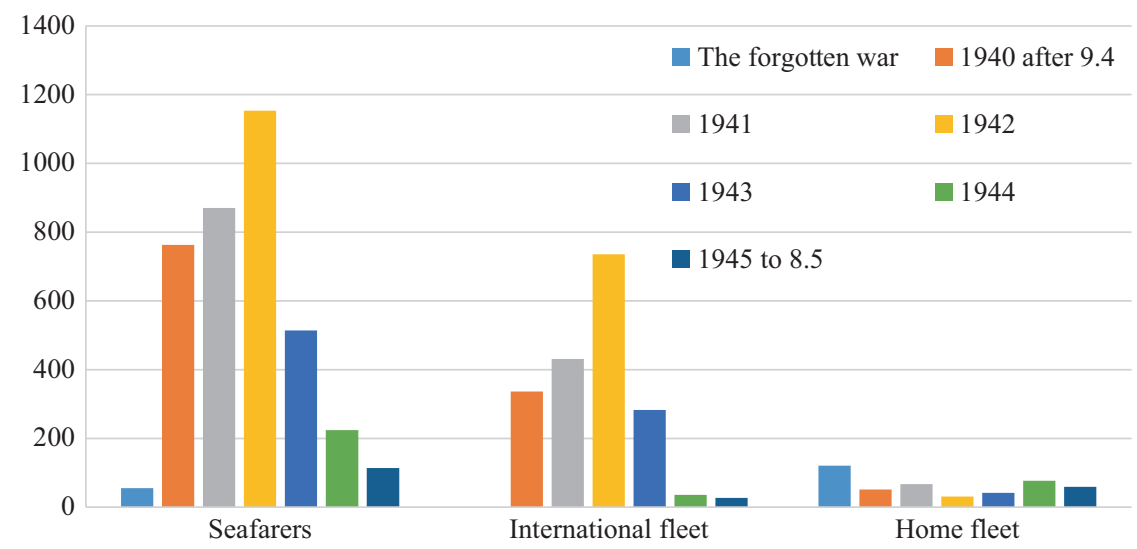

Fig. 5.1 Losses during the Second World War, persons and 1000 grt, 1939-45. (Source: Statistics Norway $(2000,115)$. See footnote)

was a gradual increase in losses as a result of increasing hostilities, before a combination of a reduction of the submarine threat and efficient measures, again including convoys, managed to alleviate the situation. ${ }^{32}$

Slightly more than 10,000 Norwegians_-9379 men and 883 womendied as a direct result of the war. ${ }^{33}$ The losses of the Norwegian military accounted for only one-fifth of this. ${ }^{34}$ The highest single group of casualties among Norwegians came from seafarers in the merchant marine. At sea, more than 3600 civilians lost their lives-including 70 women. Consequently, seafarers made up more than a third of all the Norwegian deaths. Their sacrifice was extremely important for the final outcome of the war.

\footnotetext{
${ }^{32}$ Figure 5.1: Based on data from Statistics Norway (2000), Table 116, 115. See the original source for more information on the basis for the original data. The figures differ marginally from those in Statistics Norway (1948), Table 131b, 248, mainly as a result off differences in the periodization. Before the German invasion on 9 April 1940, all ships were registered as belonging to the home fleet.

${ }^{33}$ Based on data from Statistics Norway in Søbye (1999). While around 10,000 Norwegians lost their lives at home and abroad as a direct result of the war, around 13,000 Russian and almost 3000 Yugoslav prisoners of war lost their lives on Norwegian soil; Fure $(1999,37)$.

${ }^{34}$ In addition to the 2000 deaths in the Norwegian military, almost 700 Norwegians died while fighting for "the other side" on the Eastern Front.
} 


\section{Peacetime: Rebuilding the Fleet}

When the war in Europe was over, the challenges facing the Norwegian shipping industry were substantial. Half of the fleet was gone, and the remaining ships were not in good shape, as maintenance had not been a priority during the difficult period. When the war ended, it had not been decided when the ships would be returned to the owners or how and when the outstanding balances would be settled. While the shipowners were interested in regaining control of their tonnage as soon as the war was over, it was evident that the political desire-at the international level-was to maintain strategic command of the merchant ships. The aim was to ensure rational and efficient management of the world fleet, thus aiding the relief and rebuilding efforts.

According to an agreement from the late summer of 1944, the United Maritime Authority (UMA) would coordinate the merchant marines of important Allied countries for a period of six months after the end of the war. The new intergovernmental organization commenced their operations in May 1945, but for the first months the Norwegian ships remained requisitioned by the authorities. In October, the ships were time chartered on "UMA-terms" to the authorities. Two shipowners that had fled from Norway during the last stages of the war, Fredrik Odfjell and Leif Høegh, represented Norway in the United States and the UK, respectively. The choice of two "industry men" as Norwegian representatives in the executive of this important intergovernmental and bureaucratic organization says something about the Norwegian authorities' experience with and trust of shipowners following the five years of cooperation abroad. This kind of delegation would be quite common throughout the post-war period-even when there was massive discussion and disagreement about domestic matters, the authorities let the shipowners' delegates represent the country in several international institutions. ${ }^{35}$

John Oscar Egeland, one of the most prominent industry "insiders" and Director of Norges Rederforbund 1948-1953, sketched two main

\footnotetext{
${ }^{35}$ Egeland (1971, 18).
} 
tasks for the shipowners after the war. The first was to regain control of their tonnage as soon as possible. The second was to obtain new vessels to compensate for the wartime reductions in the fleet. ${ }^{36}$

The main problem was of course the major losses during the war. There had been some minor additions to the fleet. Twelve Liberty-ships, general cargo carriers of around 7000 gross register tons (grt), four smaller C1-A general cargo carriers and eight T2-tankers of around 10,000 grt had been transferred from the United States in the period January 1943April 1945 as part of the Lend Lease agreement. ${ }^{37}$ However, although Norwegian shipowners bought an additional 46 Liberty ships from the US after the war, and another eight second-hand from owners in Denmark and Panama, both the relative and absolute position of Norwegian shipping was severely deteriorated. ${ }^{38}$

Still, there was undoubtedly a role for shipping in the Norwegian economy. A 1947 newspaper article points out that shipping "is a dream investment" in a national perspective as it has "a high turnover and high revenues for the country, with only a modest need for labour." ${ }^{39}$ The authorities subscribed to this idea. After the war, the rebuilding of the fleet became a national priority. The Labour government-which took over in 1945 supported by an absolute majority in the Parliament-gave precedence to industries that could neutralize the deficit on the Balance of Trade and thus secure valuable foreign currency, in other words US dollars. The mainstay of this policy, in addition to shipping, became export-oriented and energy-intensive manufacturing.

The idea of shipping as a key industry in Norwegian policy-making is a stark contrast to a 1953 paper by the leading shipping lobbyist—chief economist Johan Seland of Norges Rederforbund-who painted a really grim picture: shipping's role in the Norwegian economy had declined. Norway's position in world shipping in general, and within tanker transports in particular, was weaker than before the war. Shipping companies

\footnotetext{
${ }^{36}$ Egeland (1971, 17).

${ }^{37}$ Basberg (1993, 176-177). In total, more than 500 ships were transferred from the United States to other Allies. Two countries received more than Norway's 24 ships-341 vessels were transferred to the UK and 93 went to the Soviet Union.

${ }^{38}$ Fon $(1995,73)$.

${ }^{39}$ Verdens Gang, 190347, 6.
} 
had serious financing difficulties and even if markets were good, they would see their capital depleted. ${ }^{40}$ Moreover, the Norwegian tax regime was worse than in any other shipping nation, and this forced shipping companies to increase their debts, according to Seland.

What had happened between 1947 and 1953 that gave such different results?

A crucial element of economic policy is striking the right balance between the power of the state and the freedom of individual economic agents. Nortraship and the war experiences had shown that in special circumstances there were reasons to tilt this balance strictly to one side. In the first post-war decades, the authorities in Norway took on a much more active role in economic development than they had done before the war. This was a development that was similar to most European countries. However, in Norway the coalition between interventionist politicians and bureaucrats with a strong belief in planning was more powerful, and lasted longer, than in most countries in Western Europe. One reason for this was the broad support for the Labour Party [Arbeiderpartiet] in the post-war elections.

With the gradual rebuilding of Norway, and of the world economy, access to foreign currency became one of the main concerns of the authorities. Export revenues were lower than before the war, while purchases abroad were larger, and the central bank had been forced to reduce its reserves in order to purchase the dollars needed to finance imports. The rebuilding of the merchant fleet was one of the main expenses abroad, but this was initially a desired development. The shipping industry was expected to play a key role as an earner of foreign exchange, and in 1945 and 1946 Norwegian shipowners were allowed to "buy or order all the tonnage that they desired [and] practically all requests for currency to buy ships were granted." ${ }^{41}$ In total, around NOK2 billion-more or less equal to the currency reserves earned by the merchant marine during the war-were granted. The authorities were involved as buyers, mediators and distributors, in addition to providing guarantees.

\footnotetext{
${ }^{40}$ Seland $(1953,5-6)$.

${ }^{41}$ Thowsen (1986, 11-12). Thowsen's article is one of the most comprehensive reviews of the reconstruction of the Norwegian fleet after the war, with a particular emphasis on the political side, including the licensing regime.
} 
By the end of 1946, the fleet was back at the pre-war level, but only when newbuilding contracts are included. However the revenues from shipping failed to live up to expectations. There were two reasons for this. First, the smaller fleet—contracts do not make money-and a high proportion of relatively outdated ships, had a negative effect. Second, the freight rates were controlled for some time after the war, and due to the new tonnage built during the war, there was no post-war boom.

In the minds of the bureaucrats and politicians, the shipping sector's position was one important reason for the reduced foreign exchange reserves. The currency regulations that were used to the benefit of Norwegian shipping immediately after the war were now used to reduce growth. For shipping companies, their access to financing came to be dependent upon a number of features, including war losses, revenues from vessel sales and the markets in which the ships operated - those that ensured freights were paid in dollars were preferred. The restrictions that the authorities introduced clearly favoured the large Norwegian shipping companies, in particular those that were engaged in the liner trade. The Sterling Crisis in 1947where the premature convertibility of the British pound revealed the extent of Europe's dollar difficulties — made the authorities apprehensive.

In the autumn of 1947 the licensing of new contracts abroad was stopped temporarily. The possibility of ordering ships was resumed after a while if the owner could - through vessel sales abroad or freight revenues-ensure that the contracting did not create a need for foreign exchange. This period of access to "currency neutral" financing lasted until March 1948. Subsequently, there was sporadic granting of licences, before a full contracting ban was introduced in 1949 and 1950Norwegian shipping companies were simply not allowed to order ships abroad.

The rebuilding of the merchant fleet was at the centre of the debate about the authorities' right-and ability_to direct the economy. Some wanted more control, others less. A Communist Member of Parliament, Emil Løvlien, suggested that the government had given up control of economic policy, and transferred policy design to the shipowners. ${ }^{42}$ The

\footnotetext{
${ }^{42}$ Norway, Parliament, Forhandlinger i Stortinget No. 70, 15 April 1948, 550-557. Løvlien's speech was so long that the Parliament had to break for lunch. When they returned from the meal, he warned against the "completely dangerous" Marshall Plan, "a morphine injection" that should be
} 
subsequent year, when the restrictions on contracting had been introduced, a member from the Farmers' Party [Bondepartiet] was extremely critical about how the authorities dealt with business and the private sector. Probably inspired by Friedrich Hayek's recent writings, he suggested that the ban was the start of a road that would ultimately lead to "a bureaucratic, state-directed dictatorship. ${ }^{43}$

The restrictions that the Labour government had introduced were extremely harmful, according to the shipowners and the Conservatives. Initially their opposition was limited - the state of the market did not encourage new orders anyway. However, when the shipping market boomed in the early 1950s as a result of the Korean War, the criticism was massive: the ban on contracting had enabled Greeks to take over profitable tanker contracts. The focus on liner vessels, with stable rates, had displaced investments in ships for more lucrative markets. The government had destroyed the competitiveness and profitability of Norwegian shipping.

In response to these accusations, the government was quick to point out the privileged access to foreign exchange that shipping had in the immediate post-war years. They saw the restrictions as a necessary measure aimed at averting an acute currency crisis. The end of the ban in 1951 unleashed a rush of new contracts, but by then newbuilding prices had increased dramatically and the waiting time for delivery was long. In the end, the ships were delivered when the boom was over.

\section{Aftermath: Rehabilitation of the Seafarers}

Norwegian soldiers returning from abroad and the members of the Hjemmefront [Home resistance] were welcomed as heroes in May 1945there were parties and public parades, flowers and flags. The war sailors

avoided. At the time, Løvlien was one of 11 representatives from Norges Kommunistiske Parti [the Norwegian Communist Party], which had received 11.9 per cent of the votes in the 1945 election. Arbeiderpartiet [the Labour Party] had an absolute majority, with 76 of the 150 representatives, after receiving 41 per cent of the votes. In 1957 Løvlien became the last Member of Parliament to be elected on the Communist Party ticket.

${ }^{43}$ Gabriel Moseid in Norway, Parliament, Forhandlinger i Stortinget, 22 March 1949, 477. 
did not receive such a warm welcome-they basically returned unannounced, without a fanfare. Some arrived in the spring or summer of 1945, some arrived that autumn, others in 1946 or even 1947. Most of them arrived according to their ships' schedules. Some stayed abroad, having established relations in Canada, the United States or the UK, while others had to wait until they could find a Norwegian ship to take them home. In the first post-war period, passenger ships were usually reserved for the movement of troops, but one exception was when more than 800 war sailors - all injured or ill-arrived in late July with the steamship Bergensfjord. ${ }^{44}$

The vessel Bergensfjord is itself an illustration of the action-filled war years; the ship was rebuilt to carry troops and transported some 165,000 passengers - soldiers, prisoners of war and refugees all over the globe. Travelling more than 300,000 nautical miles-equal to 14 times around the Equator- "Lucky Bergensfjord" moved in dangerous waters and was on the front line during the invasion of Sicily. ${ }^{45}$ The ship's seafarersboth the crew and its injured and ill passengers_-had been in the line of fire for more than five years. It was a war experience that was very different from what most Norwegians had been through.

At the start of the war, Norwegian seafarers had been paid for their high-risk work. Before the Nazi invasion, they received a war-risk premium that could be up to 300 per cent of their basic salaries, depending on the zone in which the ship was sailing. In June 1940, after Norway entered the war, the British demanded that the wages of Norwegian and British seafarers should be aligned. As a result, the war-risk bonus was reduced to NOK100 per month. For ordinary seamen this implied a decline of up to NOK500 per month, for captains as much as NOK3000.

Although the war risk did not disappear, the premiums apparently did, to appease the British. Given that the premium reduction was an advantage to the British charterers, one shilling per dead weight ton per month was deposited into a special account, to be used "for the benefit of the seamen after the war." ${ }^{46}$ This account is often referred to as "Nortraship's

\footnotetext{
${ }^{44}$ Virkesdal (1991, 17).

${ }^{45}$ Ljone (1982).

${ }^{46}$ Hodne (1992, 174).
} 
secret fund," as it was important that British seafarers did not know that their Norwegian colleagues were paid more. For the Norwegian seafarers, the fund was "a public secret." After the war, the existence and use of this fund was shrouded in controversy. By the end of 1947 the fund, including interest, amounted to almost NOK44 million. Who did the money belong to?

A government committee headed by Arne Sunde and with participation from the four major maritime unions, in 1947 suggested that the money be used for widows and children of seafarers that died during the war, ill and disabled seafarers, older seafarers, and so on. This solution was accepted in Parliament the following year. But parallel with this, a group of war sailors were fighting in the courts, arguing that the money in "the secret fund" belonged to them, and consequently should be divided among those who had participated.

In 1954 the Supreme Court rejected the seafarers' case. However, media pressure in the late 1960s and early 1970s led to a revitalization of the question, and in 1972 Parliament awarded an ex gratia payment of some NOK155 million to the war sailors and their surviving relatives. It is very unfortunate that Nortraship - this well-functioning mixture of private ownership and government intervention, of profit and patriotism-is most famous for its "secret fund," which tainted the seafarers' post-war relations with the shipowners and the authorities.

The fund was only one of the many difficult fights that the Nortraship seafarers had to deal with after the war. An everyday example is the fact that some of them had been abroad for so long that they had been removed from the electoral roll. In other words, those who had fought for Norway's freedom were not allowed to participate in the Parliamentary elections. Others were asked to prove their patriotic attitude, or were called up for compulsory military service, after more than five years on the front line. ${ }^{47}$

Some questions were dealt with in a more pragmatic manner. In many instances, families in Norway had been paid while the breadwinner was abroad. This implied that the seafarer could owe money to his employer

${ }^{47}$ See Virkesdal $(1991,15)$. 
when he returned, if he had not "sailed enough" to cover the advances. Shipowners would often quietly "forget about" this, and redeem the debts.

The Norwegian authorities were less forthcoming. War sailors received lower pensions than soldiers and those that had been prisoners in Norway-a Parliamentary minority suggested that seafarers should not receive war pensions at all. The term "war sailor syndrome" was coined, a variety of the "KZ syndrome" that affected those surviving the concentration camps. ${ }^{48}$ Symptoms included difficulties in adapting to normal life, nightmares, angst, depression, lack of concentration and insomnia. The journalist, Oddvar Schjølberg, refers to this as "the eternal war of the war sailors." 49

Norwegian seafarers and bereaved families had to fight Norwegian bureaucrats for their rights, and years and even decades passed before they were given recognition and compensation. Up until the late 1960s, they had to prove that their problems were a direct result of the war, in order to receive war pensions. In 1968, the burden of proof was reversed: the authorities had to prove that there was no causality between the war and the health problems. ${ }^{50}$ As Jon Michelet phrased it: after the war, "we rebuilt the country, but not the people." 51

When Norway was invaded in April 1940, around 3200 foreign seafarers worked on the ships that were about to become the Nortraship fleet, and during the first years of the war the proportion of foreigners increased from 12 to 25 per cent. Almost 1000 foreigners lost their lives while working on Norwegian ships. They came from 36 different nations, and the largest losses of lives were among British (323) and Chinese (252) seafarers. ${ }^{52}$ The compensation that was paid out was arbitrary, if paid at all. Many received ex gratia payments-money given based on goodwill, rather than legal claims_-others received nothing.

\footnotetext{
${ }^{48}$ See Askevold et al. (1976), Hartvig (1977) and Hansson (1967).

${ }^{49}$ Schjølberg (2014).

${ }^{50}$ On the struggle to get the right to receive war pensions, see Hjeltnes (1997, 458-474).

${ }^{51}$ Aftenposten, 05102013, 2-3.

${ }^{52}$ The information on foreign war sailors is mainly from Rosendahl (2017). In addition to people from 36 different nations, one stateless person lost his life; Jan Alexis Molotov died when MS Fernhill was sunk by a submarine in August 1942.
} 
The manner in which Norway treated the war sailors was not particularly appreciative. But the neglect gradually became evident, and an apology from the Minister of Defence was made in public: "The story of our war sailors is a shocking narrative. About a society that was not properly prepared to take care of some of the biggest war heroes. About rejection and denial. You, the war sailors, should not be blamed - you expected that society would appreciate your efforts. But you were disappointed. As a society, we let you down. Today I therefore apologise, on behalf of the Norwegian authorities, for the treatment that war sailors were subject to after the war." 53

The Minister of Defense was Anne Grethe Strøm-Erichsen from the Labour Party. The year was 2013. For the vast majority of the war sailors, the apology came too late.

The Hall of Remembrance for Sailors [Minnehallen] outside Stavern was unveiled in 1926 to commemorate the Norwegian sailors that died during the First World War. The names of fallen sailors are inscribed on a series of copper plates, and after the Second World War almost 3500 names were added to the 1748 from the First World War. The last addition came on 8 May 2017, when 956 names of foreigners were added. Among those that financed the new plates were the Norwegian Shipowners' Association and other companies and foundations in the Norwegian shipping industry. Another important financial contributor was the author Jon Michelet, who has shown how powerful literature can be in shaping our knowledge and ideas about the world in which we live and die.

\section{Bibliography}

F. Askevold, E.A. Løchen, \& O. Sjaastad (1976) 'Krigsseilersyndromet', Tidsskrift for Den Norske Lageforening, 96, 868-872

B.L. Basberg (1993) 'Nortraship - Alliert og konkurrent', Handelsflàten $i$ krig 2 (Oslo: Grøndahl og Dreyers Forlag AS)

\footnotetext{
${ }^{53}$ Minister of Defense, Anne Grete Strøm-Erichsen's speech given when the monument honouring the war sailors was unveiled, 030813. [regjeringen.no/no/aktuelt/mote-med-krigseilere-ogparorende-risor/id733139/] [Read 051017].
} 
K.W. Bird (2006) Erich Raeder - Admiral of the Third Reich (Annapolis: Naval Institute Press)

B.F. Braumoeller (2010) 'The Myth of American Isolationism', Foreign Policy Analysis, 6:4, 349-371

W. Churchill (1950) The Second World War, Volume III, "The Grand Alliance", 6th edition 1985 (New York: Houghton Mifflin Company)

J.O. Egeland (1971) Vi skal videre: Norsk skipsfart etter den annen verdenskrig, perioden 1945-1970 (Oslo: H. Aschehoug \& Co.)

A.M. Fon (1995) 'En stormakt i tørrbulk. En økonomisk-historisk analyse av norsk tørrbulkfart 1950-1973', PhD-thesis (Bergen: Norges Handelshøyskole)

O.B. Fure (1999) 'Norsk okkupasjonshistorie. Konsensus, berøringsangst og tabuisering', in S.U. Larsen (ed) I krigens kjølvann: Nye sider ved norsk krigshistorie og etterkrigstid (Oslo: Universitetsforlaget)

C.J. Hambro (1945) Taler i krig (Oslo: Gyldendal)

P. Hansson (1967) Hver tiende mann måtte dø: fra konvoifarten under siste krig (Oslo: Gyldendal)

P. Hartvig (1977) 'Krigsseilersyndromet. En undersøkelse og en diskusjon av begrepets innhold', Nordisk psykiatrisk tidsskrift, 31, 302-313

E.O. Hauge \& V. Hartmann (1951) Flukten fra Dakar (Bergen: J.W. Eides Forlag)

G. Hjeltnes (1995) 'Sjømann - Lang vakt', Handelsflàten i krig 3 (Oslo: Grøndahl og Dreyers Forlag AS)

G. Hjeltnes (1997) 'Krigsseiler: krig, hjemkomst, oppgjør', Handelsflàten i krig 4 (Oslo: Grøndahl og Dreyers Forlag AS)

F. Hodne (1992) Norsk økonomi 1900-1990 (Oslo: TANO)

C.F. Horne (1923) Source Records of The Great War (New York: National Alumni)

L. Høegh (1970) I skipsfartens tjeneste (Oslo: Gyldendal)

L. Lindbæk (1948) Tusen norske skip (Oslo: Gyldendal Norsk Forlag)

O. Ljone (1982) Bergensfjord - skipet som overlevde alt (Oslo: Gyldendal Norsk Forlag)

E. Mossige (1989) Storrederiet Nortraship - Handelsflaten i krig (Oslo: Grøndahl)

E.D. Næss (1977) Autobiography of a Shipping Man (Seatrade, London)

T.L. Nilsen \& A. Thowsen (1990) Handelsflaten i krig 1939-45 (Bergen: Bergens Sjøfartsmuseum)

L. Pettersen (1992) Hjemmeflàten. Mellom venn og fiende (Oslo: Grøndahl Dreyer)

A.H. Rasmussen (1964) Menn uten medaljer: En saga om og av norske sjøfolk (Oslo: J.W. Cappelens forlag) 
B.T. Rosendahl (2015) 'Patriotism, money and control - Mobilization of Norwegian merchant seamen during the Second World War', Scandinavian Journal of History, 40:2, 159-194

B.T. Rosendahl (ed) (2017) De var også krigsseilere (Kristiansand: Stiftelsen Arkivet)

O. Schjølberg (2014) Krigsseilernes evige krig (Larvik: Liv Forlag)

J. Seland (1953) Oversikt over momenter som kan belyse utviklingen i årene fremover av verdenshandelen, verdensflàten og Norges flàte samt over de norske skattereglers virkning for skipsfartsnaringen og andre lands skatteregler (Oslo: Norges Rederforbund)

Statistics Norway (1948) Statistiske oversikter 1948 (Oslo: Statistiske Sentralbyrå) Statistics Norway (2000) Statistisk Årbok 2000 (Oslo: Statistics Norway)

S. Steen (1948) Norges krig, 1940-1945, Vol. II (Oslo: Gyldendal Norsk Forlag)

E. Søbye (1999) Statistikk mot år 2000. Krigsdødsfallene under andre verdenskrig. http://www.ssb.no/befolkning/artikler-og-publikasjoner/krigsdodsfalleneunder-2-verdenskrig (15.03.16)

A. Thowsen (1986) 'Skipsfart og planøkonomi. Kontraherings- og lisensieringspolitikken overfor norsk skipsfart i den første etterkrigstiden (1945-1953)', Sjøfartshistorisk Årbok 1985 (Bergen: Bergens Rederiforening og Bergens Sjøfartsmuseum)

A. Thowsen (1992) 'Nortraship - Profitt og Patriotisme', Handelsflàten i krig 1 (Oslo: Grøndahl og Dreyers Forlag AS)

Undersøkelseskommisjonen av 1945 (1945) Underøøkelseskommisjonen av 1945, Volumes I-III (Oslo: Arbeidernes Aktietrykkeri)

Undersøkelseskommisjonen av 1945 (1947) Undersøkelseskommisjonen av 1945, Volume IV (Oslo: Arbeidernes Aktietrykkeri)

D. Vikøren (1986) Norsk skipsfart i sterk omstilling. Svekkes vår forsvarsberedskap? (Oslo: Den Norske Atlanterhavskomite)

E. Virkesdal (1991) Handelsflàten i krig (Bergen: Bergens Sjøfartsmuseum)

H. Woxholth (1965) "Kjere landsmenn", Kong Haakon VIIs taler under krigen 1940-1945 (Oslo: Hjemmenes Forlag) 
Open Access This chapter is licensed under the terms of the Creative Commons Attribution-NonCommercial-NoDerivatives 4.0 International License (http:// creativecommons.org/licenses/by-nc-nd/4.0/), which permits any noncommercial use, sharing, distribution and reproduction in any medium or format, as long as you give appropriate credit to the original author(s) and the source, provide a link to the Creative Commons license and indicate if you modified the licensed material. You do not have permission under this license to share adapted material derived from this chapter or parts of it.

The images or other third party material in this chapter are included in the chapter's Creative Commons license, unless indicated otherwise in a credit line to the material. If material is not included in the chapter's Creative Commons license and your intended use is not permitted by statutory regulation or exceeds the permitted use, you will need to obtain permission directly from the copyright holder.

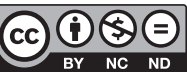

